\title{
Spatial Approach to Medium-term Coastal Evolution in South Sicily (Italy): Implications for Coastal Erosion Management
}

\author{
Departmento de Geología \\ Facultad de Ciencias del Mar y Ambientales \\ Polígono Río San Pedro s/n \\ 11510 Puerto Real \\ Cádiz, Spain \\ giorgio.anfuso@uca.es
}

José Ángel Martínez del Pozo and Giorgio Anfuso*

\begin{abstract}
MARTÍNEZ DEL POZO, J.Á. and ANFUSO, G., 2008. Spatial approach to medium-term coastal evolution in south Sicily (Italy): implications for coastal erosion management. Journal of Coastal Research, 24(1), 33-42. West Palm Beach (Florida), ISSN 0749-0208.

Four sets of maps and aerial photographs have been integrated into a Geographic Information System (GIS) project to investigate coastal changes along a $60-\mathrm{km}$-long littoral sector in south Sicily, Italy. The beaches studied recorded significant morphological changes essentially related to the presence of human structures that interrupted littoral drift. Most of the investigated beaches experienced progressive erosion because of sediments being trapped by human structures resulting in the formation of wide beaches on the updrift side and erosion downdrift. The latter has often been counteracted by the construction of breakwaters. However, local planning authorities did not carry out an assessment of the impacts related to the construction of harbours and ports and their successive enlargement. This article proposes alternative actions concerning the possible future erosion management of the studied littoral.
\end{abstract}

ADDITIONAL INDEX WORDS: Shoreline trend, erosion, human impacts, management.

\section{INTRODUCTION}

Corresponding with globally rising sea levels, coastal erosion problems have been growing during past decades because human activities and constructions are exceedingly close to the shoreline (BIRD, 1996). This has enhanced scientific interest in coastal erosion processes, which have been investigated over various timescales using a variety of methods and data sets (KOMAR, 1998; SHORT, 1999).

Satellite images, vertical aerial photographs, and other techniques have been used to study changes at weekly, monthly, and seasonal periods (CROWELL, LEATHERMAN, and Buckley, 1991, 1993; Dolan, Fester, and Holme, 1991; El-Asmar, 2002; Gorman, Morang, and LARson, 1998; JimÉNEZ and SHÁNCHEZ-ARCILlA, 1993; JimÉNEZ et al., 1997; SMITH and ZARILLO, 1990).

Moreover, aerial photographs, maps, charts, and satellite images are especially useful in the reconstruction of coastline changes over time periods from years to decades and over medium spatial scales (from 1:18,000 to 1:30,000) and in observing the distribution of coastal types, land uses and the evolution of dune fields (DolAn et al., 1980; Domínguez, ANFUSO, and GARCIA, 2005; FISHER and Overton, 1994; Forbes et al., 2004; JimÉNEZ et al., 1997; LEATHERMAN,

DOI:10.2112/05-0598.1 received 30 September 2005; accepted in revision 27 February 2006.

This work was partially funded by the Provincia Regionale di Ragusa Administration (Sicily, Italy), and it is a contribution to the Andalusia P.A.I. Research Group RNM-328.

* Corresponding author.
1983; MRIDE et al., 1991; TANEY 1961). Recently, the use of these different documents has been improved with Geographic Information Systems (GISs) and computer-assisted multivariate analysis (CoOper and MCLAughlin, 1998; Kelly, 2000).

In this work, aerial photographs integrated into a GIS project, have been used to reconstruct the coastline evolution during a 32-year period in the area between Punta Secca and Punta Castellazzo (south of Sicily, Italy). The studied coastal sector experienced significant erosion problems related to the large developments built during recent decades, primarily the construction of ports, harbours, breakwaters, summerhouses, and littoral roads. This has had a great impact on the littoral drift, justifying a need for Integrated Coastal Zone Management (CLARK, 1996). Additionally, quantification of erosion rate in the studied area is very important because shoreline retreat takes place over a human timescale. Consequently, the recorded data can be used to determine safe construction setbacks, to evaluate the efficiency of coastal protection structures, and to elaborate coastal erosion management and land use plans (BERLANGA and RUIZ, 2002; Bush, RichARD, and NEAL, 1996; Fischer and ARREDONDO, 1999; LiZÁRrAGA, APPENDINI, and FisCHER, 2001; SÁNCHEZArCiLla, Jimenez, and VALDEMORo, 1998).

\section{STUDIED ZONE}

The length of the studied area is about $60 \mathrm{~km}$ and is located between Punta Secca and Punta Castellazzo, in the southern littoral of Sicily, Italy. Coastal orientation varies from WNW- 


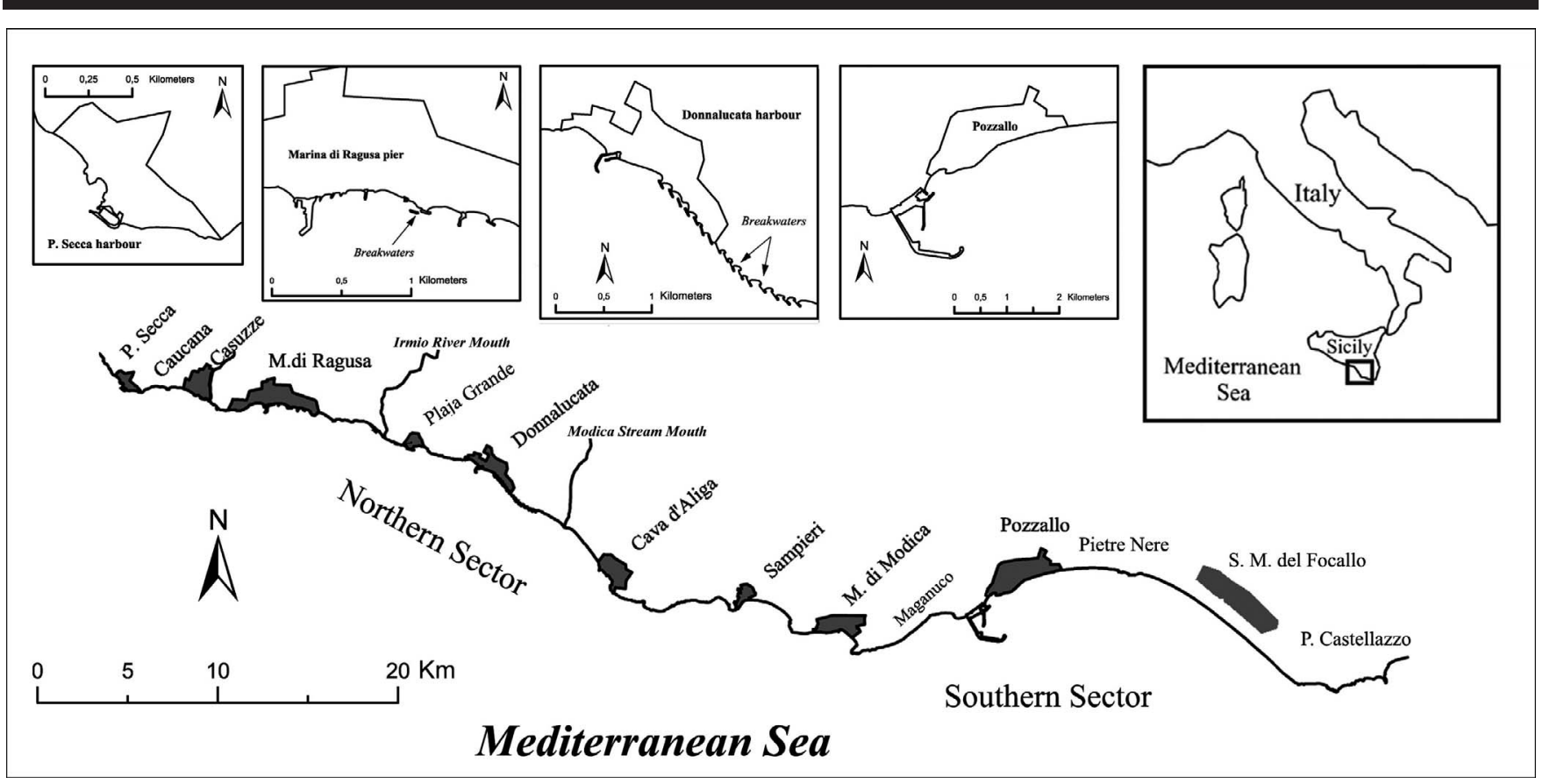

Figure 1. Location map with distribution of human structures along the studied coast.

ESE in the northern sector between Point Secca and Cava d'Aliga, to E-W in the southern sector from Cava d'Aliga to Point Castellazzo (Figure 1). The littoral is composed of sandy beaches of different widths, which are rich in quartz $(\cong 65 \%)$, carbonates $(\cong 30 \%)$ and which also contain feldspars and heavy minerals (ANFUso 1999; AMORE and RANDAZzO, 1993). The nearshore zone is very smooth (average slope 1$2 \%$ ), and large surf zones are observed, especially in the southern sector.

The beaches are backed by dune ridges and cliffs cut in sandstones, marls, and limestones. According to AMORE and RANDAZZO (1997) and ANFUso (1999), no significant sedimentary inputs to the littoral budget are derived from either cliff retreat, because eroded sediments are generally too fine, or from fluvial inputs. In fact, rivers originate predominantly from chalk catchments, and their sedimentary supplies have been greatly restricted because of the construction of weirs, dams, and artificial canalization to avoid flooding in urbanized areas.

In terms of marine climate, the zone is a microtidal environment characterized by maximum tidal variations of about

Table 1. Documents used in study of coastal evolution over 32 years in southern Sicily, Italy.

\begin{tabular}{lccc}
\hline \hline \multicolumn{1}{c}{ Type } & Year & Scale & Notes \\
\hline Topographic map & 1967 & $1: 25,000$ & \\
Aerial photographs & 1977 & $1: 17,000$ & B\&W $^{1}$ \\
Aerial photographs & 1987 & $1: 12,500$ & Colour \\
Orthophotographs & 1999 & $1: 12,500$ & Colour \\
\hline
\end{tabular}

${ }^{1}$ Abbreviations: $\mathrm{B} \& \mathrm{~W}=$ black and white.
$40 \mathrm{~cm}$, usually in the order of $10 \mathrm{~cm}$. The coast is principally affected by winds blowing from the third quadrant; winds from the second quadrant achieve greater importance during the autumn and spring. Unfortunately, no wave-gauges exist in the area, and information about wave climate was obtained from the Littoral Environment Observation (LEO) measurement system, based on visual wave observations in the open sea. Major storms hit the coast most frequently from the third quadrant, with significant deep-water wave heights $\left(H_{s}\right)$ of $8 \mathrm{~m}$ and periods $(T)$ of 11 seconds. Minor storms approach from the second quadrant, with $H_{s}=5.5 \mathrm{~m}$ and $T=$ 10.5 seconds.

\section{METHODS}

To characterize the coastal environment, detailed field observations have been carried out several times over recent years (i.e., from 2000 to the present), during both winter and summer conditions. These observations enabled the evaluation of the morphodynamic state and the behaviour of the investigated beaches, as well as the presence of longshore bar and dune dynamics. On the other hand, the distribution of human structures and their characteristics have been described by ANFuso $(1993,1999)$ and ANFuso and MARTínez (2005).

Also, a range of aerial photographs and maps from different years and timescales have been used to reconstruct and quantify shoreline evolution over a period of 32 years according to STAFFORD (1971), DolAN et al. (1980, 1991), LEATHERMAN (1983), JIMÉNEZ et al. (1997), and PAJAK and LEATHERMAN (2002) (Table 1).

These documents have been scanned, geo-referenced, and 
computer-rectified to eliminate effects of scale and distortion (CrOWEll, LeATHERMAN, and BuCKLEy, 1991; LiLlesAND and Kiefer, 1987; Moore, 2000). Ground Control Points $(\mathrm{GCPs})$ for photo registration have been obtained from the geo-referenced orthophotographs of 1999, and all the information has been presented in Gauss-Boaga Coordinates (zone 2). Taking into account the smooth topography of the studied area, a polynomial transformation has been applied in the registration process (CHUVIECO, 2000). The number of GCPs used varied from one photograph to another (from 9 to 15 units), and their position has been located in unequivocal places (THIELER and DANFORTH, 1994).

The error related to the distortion of the photographs (ANDERS and Byrnes, 1991; CROWELl, LEATHERMAN, and BuCKLey, 1991; Dolan et al., 1980; Moore, 2000) has been solved and controlled in the geo-referenced documents with visual estimations by comparing the registered photo with the base map, and through the root mean square error (RMSE), allowing the photographs a geometrical error of approximately $\pm 5 \mathrm{~m}$.

The precision and accuracy of aerial photogrammetric measurements depend also on the difficulties of locating the shoreline position. Typically, the shoreline is taken as the water line, especially in microtidal environments (DoLAN et al., 1979, 1980; Douglas and Crowell, 2000; LeatherMAN, 1983; PAJAK and LEATHERMAN, 2002), or as the seaward vegetation limit, dune foot, or cliff top, in mesotidal environments (CROWELL, LEATHERMAN, and BUCKLEY, 1993; Fisher and Overton, 1994).

In this work, the shoreline position was defined as "the water line at the time of the photo" because it is in a microtidal environment.

Moreover, because it was not possible to reconstruct tidal conditions at the moment of the photo, it has been assumed that the daily water line position is subject to a maximum uncertainty of $\pm 4 \mathrm{~m}$, taking into account the intertidal slope of the studied beaches (ANONYMous, 2005; Dolan et al., 1980). Wave height effects were not considered because no storm conditions were in any one of the photographs. In addition, aerial photographs were taken at the end of summer period each year, thus damping seasonal fluctuations (CROWELL, LEATHERMAN, and BuCKLEy, 1993; MorTon, 1978).

Overall, the position of the shoreline in this study has been determined with an accuracy of $\pm 1 \mathrm{~m}$ because of the spatial resolution limitations of the photographs. Furthermore, in the 1977 and 1999 photographs, the dune-toe position was also mapped.

Taking everything into account, the whole shoreline mapping error in this study was assumed to be $\pm 10 \mathrm{~m}$. This value was obtained from the sum of the previous analysed errors involved in the mapping process and the uncertainty related with the daily shoreline variations.

Shoreline variations have been calculated for different time spans, i.e., the 1967-77, 1977-87, and 1987-99 periods, which, in this study, are referred to as short-term changes according to the terminology of CROWELL, LEATHERMAN, and BUCKLEY (1993). Distances (calculated along 70 transepts regularly spaced along the littoral) and surfaces variations have been measured between two successive coastlines. Fur- ther, the 1977 coastline has been compared with that of the 1999 one to obtain a perspective on the overall evolution of the littoral over a time span of 22 years, referred to as medium-term time fame (CROWELL, LEATHERMAN, and BUCKLEY, 1993). It is important to note that the 1977 geo-referenced photographs were preferred to the 1967 geo-referenced map $(1: 25,000)$ and were used as the reference data because of their superior resolution. In the obtained figures, shoreline variations lower than $\pm 10 \mathrm{~m}$ were not displayed, according to the previous assumptions about the shoreline mapping error.

\section{RESULTS}

\section{Areas of Accreting Shoreline}

Important accretion areas were observed mostly close to harbours and ports, usually on the west side of the aforementioned structures. Accretion was also observed on a number of beaches that were not affected by human structures.

At Punta Secca, the beach showed significant cycles of erosion and accretion (Figure 2), but for several years, there has been a quite stable beach close to the eastern side of the harbour. The harbour structure traps sediments coming from neighbouring beaches (Caucana and Casuzze), causing erosion to occur.

West of the harbour, at Marina di Ragusa, certain changes in the beach have been observed. The beach has migrated eastward, and during recent years, it has been welding to the harbour structure. In this case, as previously recorded in Punta Secca, the extended docks blocked the newly formed beach.

At Donnalucata, the beach west of the harbour is heavily accreted at a maximum rate of $6 \mathrm{~m} / \mathrm{y}$ over the 1977-87 period.

In the southern part of the littoral, the structure of Pozzallo port begins on an offshore dock joined to the mainland by a pier, which probably does not greatly affect littoral drift. As observed in Figures $3 \mathrm{a}$ and $3 \mathrm{~b}$, the same beaches suffered both erosion and accretion, related to the beach plan formpivoting processes, linked to opposite drifts. After the construction of an extended groin/breakwater to provide vessels with shelter from southwesterly waves (Figure 3c), port structures have had an important influence on the adjacent eastern and western beaches because the beaches readjusted their equilibrium plan forms. On one hand, Maganuco beach recorded a huge accretion because it is more efficiently protected from easterly currents by the new structure. On the other hand, the small beach close to the structure and the large one, which includes Pozzallo and Pietre Nere areas, experienced a pivoting in plan form because of the westwarddirected transport (Figure 3c); sand enters in the port-shadow area, and it is not redistributed by westerly currents. Maximum accretion of $8 \mathrm{~m} / \mathrm{y}$ was observed in the eastern part of Pozzallo beach during the 1987-99 period.

Lastly, accretion corresponding to several pocket beaches was recorded, i.e., in Cava d'Aliga, Sampieri, and Marina di Modica (Figures 2 and 3), which were not affected in any way by human structures. These beaches experienced important enlargement at the medium-term scale, as well as dune growth and landward migration. A pivoting in plan form is 


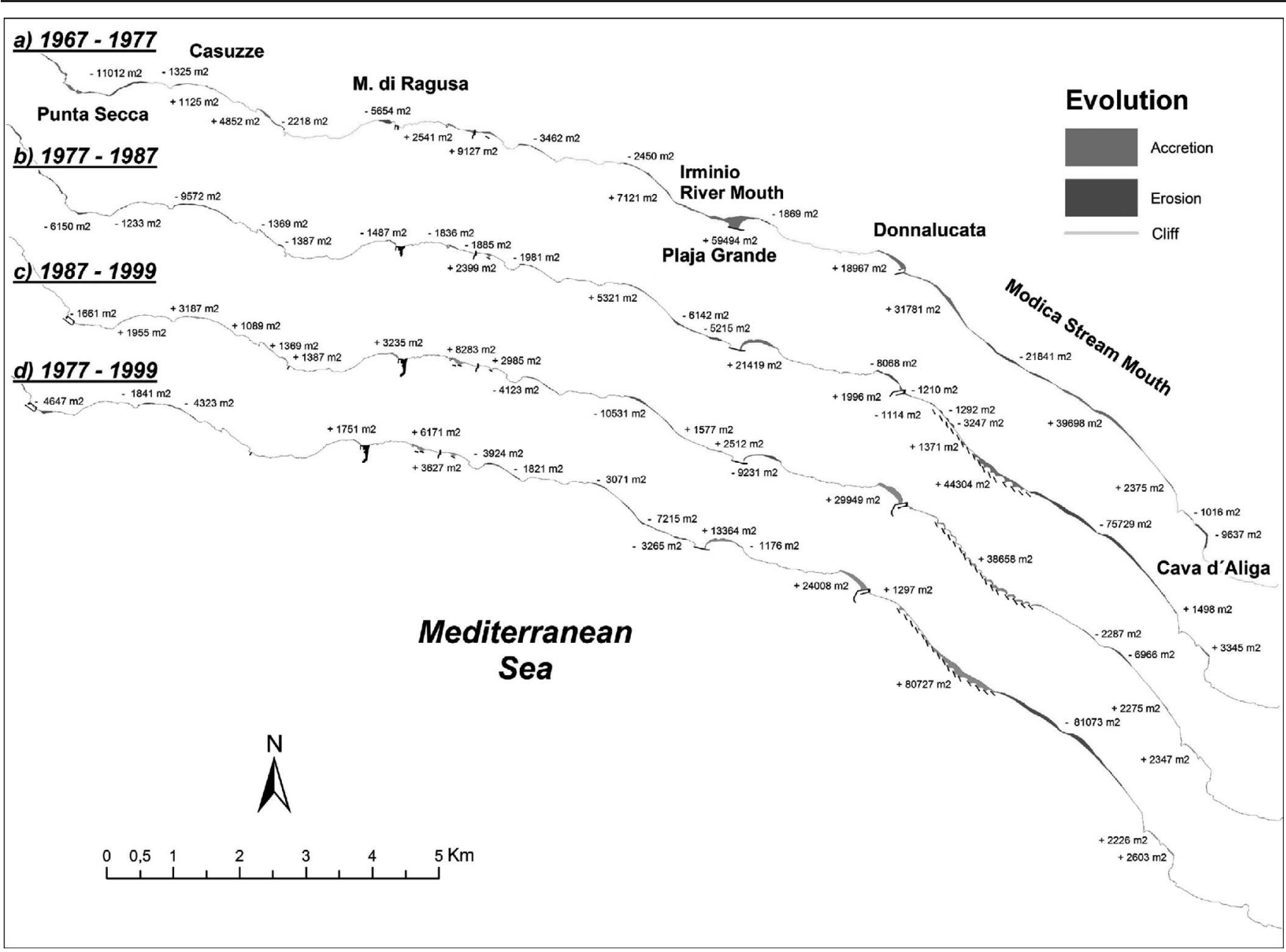

Figure 2. Coastal evolution of the northern sector, e.g., between Punta Secca and Cava d'Aliga, Italy. (a) 1967-1977, (b) 1977-1987, (c) 1987-1999, (d) 1977-1999. For a color version of this figure, see page 130.

manifest in certain places as shown in Figures 3b-d, demonstrating the importance of an eastward-directed transport that has been prevented by natural headlands.

\section{Areas of Retreating Shoreline}

Significant erosion has generally been observed close to the eastern side of harbours and ports. At these places, the coastline was artificially stabilized because of the construction of several breakwaters, but erosion problems shifted downdrift, and more breakwaters have been progressively emplaced. In other cases, erosion problems, although related to the impact of human structures, were observed in areas relatively far from human constructions. An example of this type of problem is Caucana beach, which has suffered considerable erosion (Figure 2). This erosion has accelerated over recent years, and in 1995, a littoral road and archaeological remains were undermined. Consequently, a nourishment project was carried out in 2004 to counteract the coastal retreat.

East of Marina di Ragusa (Figure 2), the three breakwaters induced a progressive formation of tombolos, with a total increase of about $20,000 \mathrm{~m}^{2}$ of beach surface, corresponding to an average accretion rate of $2 \mathrm{~m} / \mathrm{y}$. Although the two eastern structures are completely attached to the shoreline, the western one is only partially filled because of its distance from the shoreline, different orientation, and the lack of available sediments.

Further east, beach erosion is observed at the Natural Park of the Irminio River mouth. The beach has pivoted in the short-term, i.e., during the 1967-77, 1977-87, and 1987-99 studied periods (Figures 2a-c). Over medium-term time frame, the area has been eroding (Figure $2 \mathrm{~d}$ ). This erosion has accelerated during recent years, thinning the beach, eroding the dunes, and exposing an ancient deposit of fluvial pebbles along the whole beach (Figure 4). Nowadays, the beach is in a reflective morphodynamic state (SHORT, 1999), strongly contrasting with the previous dissipative state observed by AMORE and RANDAZZO (1997) and ANFUso (1999). The erosion at the Irminio River mouth is related to the loss 


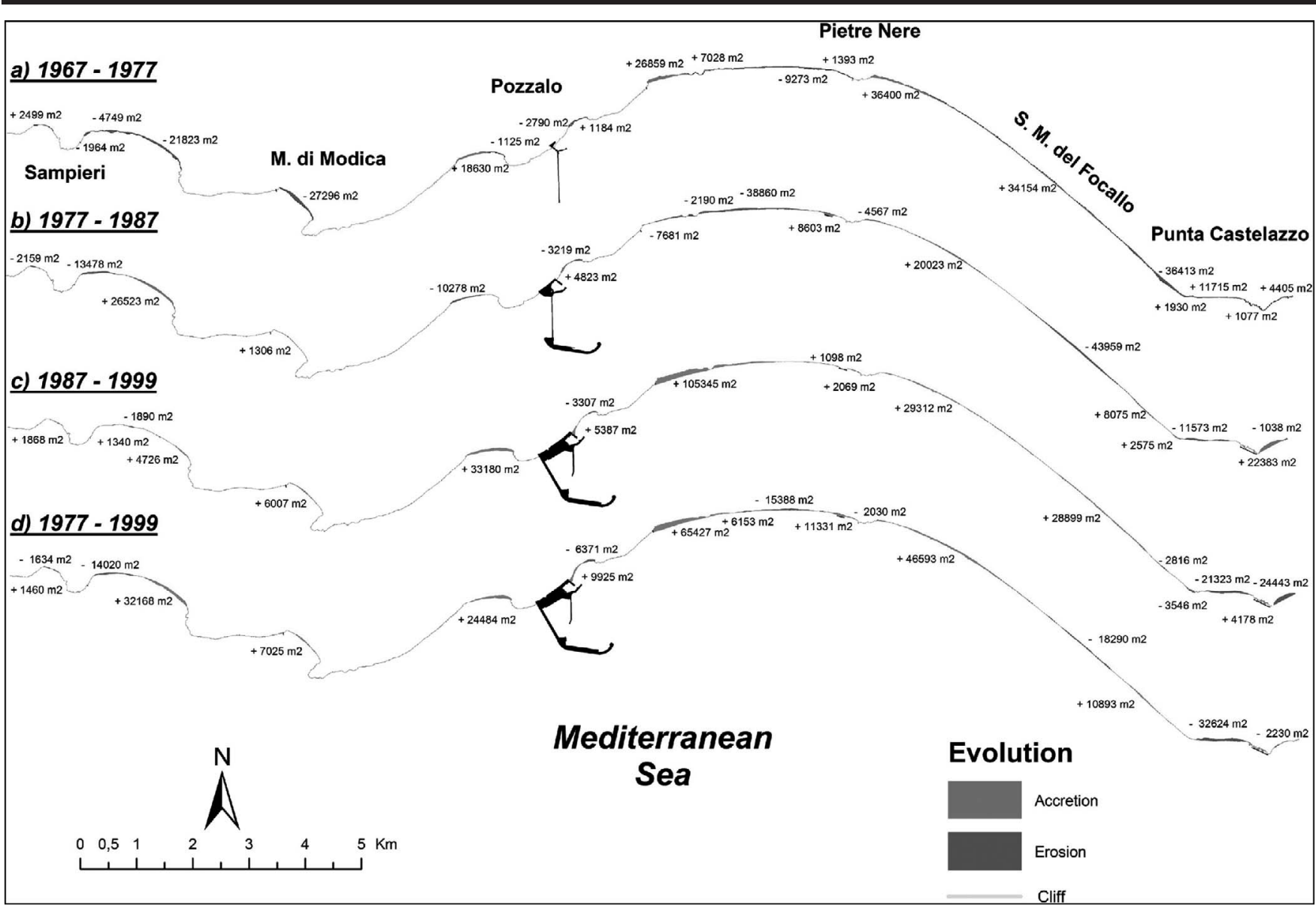

Figure 3. Coastal evolution of the southern sector, e.g., between Cava d'Aliga and Punta Castellazzo, Italy, (a) 1967-1977, (b) 1977-1987, (c) 1987-1999, (d) 1977-1999. For a color version of this figure, see page 131.

of sand trapped by the structures at Marina di Ragusa and behind the Plaja Grande breakwater.

At Plaja Grande, the breakwater was originally constructed to protect beachfront buildings but totally prevented longshore transport, resulting in the formation of a seaward-extending bulge. A huge accretion, about $70,000 \mathrm{~m}^{2}$, can be observed over the medium-term period, i.e., 1967-99.

In the 1967-1977 period (Figure 2a), the zone east of the harbour was a long, uninterrupted, and dynamic littoral unit, with great shoreline movement $( \pm 2-3 \mathrm{~m} / \mathrm{y})$ because of the longshore transport. After the enlargement of Donnalucata harbour, erosion took place, and several breakwaters were progressively emplaced eastward (Figure 2b). An important and rapid gain $\left(+45,000 \mathrm{~m}^{2}\right)$ was observed in the 1977-1987 period in the eastern part of the harbour, where the area between the structures and the beach was completely filled up; less important sedimentation took place in the western part, where tombolos were formed and erosion occurred between them. At the mouth of Modica Stream, intense erosion was experienced $\left(-75,000 \mathrm{~m}^{2}\right)$

Great accretion $\left(+40,000 \mathrm{~m}^{2}\right)$ was also recorded during the successive period (1987-99), and erosion continued at the
Modica Stream mouth, which amounted to about $2 \mathrm{~m} / \mathrm{y}$. The filling of structures took place because of sediments coming from the Modica Stream mouth, whereas no sand comes from the opposite direction because of the trapping by the Donnalucata harbour. Extensive erosion took place downdrift of the easternmost breakwater, locally counteracted with seawalls and rip-rap revetments where shorefront property was at risk. Seawalls progressively reduced beach width and, in other areas, rip-rap produced accretion. The most likely explanation for these changes is the reduction of sand removal by wave reflection and backwash (PILKEY and DiXON, 1996).

At Pietre Nere, east of Pozzallo port, and at Punta Castellazzo (Figure 3), the breakwaters produced an accretion of 11,000 and $4,000 \mathrm{~m}^{2}$, respectively. Lastly, the Santa Maria del Focallo beach showed great variability because of pivoting mechanisms (Figure 3). Over the medium-term period, the beach recorded erosion reflected by undermining processes at the littoral road (which was protected by concrete blocks), by dune escarpments, and by vegetal dune-cover degradation. The latter favoured landward migration and sand losses because of sand invading the backing littoral road. Moreover, the applied methodology was not able to totally reflect the 


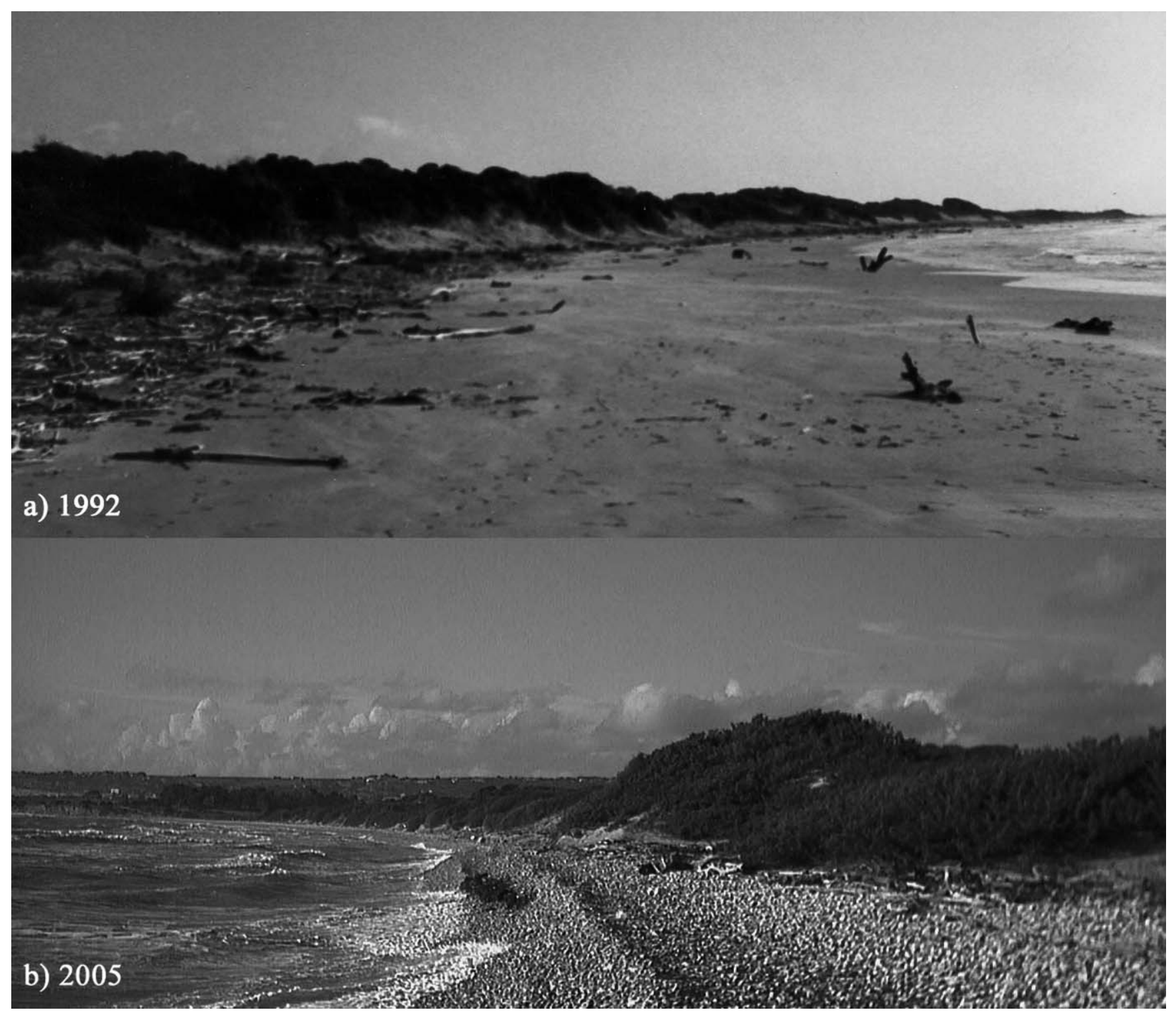

Figure 4. Coastal erosion at the Irminio River mouth: the original sandy beach has been eroded and substituted by a gravel beach. (a) Winter 1992, sighting from west to east. (b) Winter 2005, sighting from east to west. For a color version of this figure, see page 132.

general erosion that this area has been suffering. Consequently, to quantify littoral retreat in the area, dune-toe migration has been analysed, obtaining a retreat of about $30 \mathrm{~m}$ for the 1977-1999 period.

\section{DISCUSSION}

\section{Coastal Behaviour}

As observed in Figures 2 and 3, the magnitude of beach changes ranged widely in space and time. Considering the behaviour of natural beaches, i.e., the ones not directly affected by human constructions, it is possible to state that the northern sector presented less variability than the southern one.
Variability of southern beaches is related to the presence of more extended, drift-aligned beaches, rich in sediments. Often, several longshore bars have been observed, and dune growth, because of sediments coming from the sea, has been recorded at several places. In the northern sector, beaches are smaller and often interrupted by natural and human structures, which form, in most cases, a swash-aligned shoreline.

On the other hand, coastal variability decreases over time (Figures 2 and 3) because sediments have been trapped even more over recent decades by artificial structures and nowadays, only a small amount of sediment is available, and tombolos are small or nonexistent at some breakwaters at the Marina di Ragusa and the Donnalucata. A similar situation 
was observed by Bray (1997); Bray, CARTER, and HoOKE (1995); JAYAPPA, VIJAYA, and SUBRAHMANYA (2003); RUNYAN and GRIGGS (2003); and ZVIELY and KLEIN (2003).

Furthermore, longshore transport interacts with human and natural structures, giving rise to erosion and accretion areas within different littoral cells (in the sense of CARTER 1988). This process is reflected by a pivoting in beach-plan form as recorded several times in well-defined pocket beaches limited by major headlands (at Cava d'Aliga, Sampieri, Marina di Modica, Maganuco, and Pietre Nere beaches, Figure 3) or in large littoral cells delimited by natural and human structures that form fixed limits in the sense of BRAY, CARTER, and Hooke (1995) (at the Donnalucata-Modica Stream mouth system and the Pozzallo-Pietre Nere-Santa Maria del Focallo system). Free limits, following CARTER (1988) and Bray, CARTER, and HoOKe (1995) terminology, probably exist in large, open coastal sectors of the studied littoral. It is difficult, however, to determine their position, which changes according to the interaction between approaching waves and bottom morphology.

Most important of the fixed limits are represented by Donnalucata harbour and Pozzallo port, and secondarily, by Punta Secca harbour and Marina di Ragusa dock. The aforementioned structures have different influences on the littoral drift, depending on their exact location, form, and dimensions and on the characteristics of the approaching waves.

In fact, because of coastal orientation, storms approaching both from the east and the west strike the studied littoral. However, accumulation and erosion pathways around human structures demonstrate a main littoral that is southeastwarddirected, which is reflected by the decrease in the size of sediment grains (AMORE and RANDAZzo, 1993; ANFUso 1999). At places, an opposite, secondary transport is also evident.

As a result, in the northern sector, beach developments on the western sides of Donnalucata harbour and Marina di Ragusa dock indicate the predominance of a west-to-east-directed littoral drift. A secondary transport is responsible for the small accretion that took place in recent years eastward of Punta Secca harbour, which was not detected in the 1999 photographs. In the southern sector, the two opposite littoral transports are probably comparable: at both sides of Pozzallo port, accretion was recorded. Finally, other small, natural or artificial structures seem not to affect transport at all, or if they do, they affect smaller spatial and temporal scales that are undetectable by the methodology used.

\section{Indications for Coastal Erosion Management}

The use of coastal defences to combat erosion is generally linked to zones that are characteristically lacking in sediment supply; therefore, knowledge of erosion/accretion patterns is indispensable in defining effective and efficient protection methods (Komar and McDougal, 1988). During recent decades, the local governing and planning authorities have not taken into account coastal compartmentalization and sedimentary-transport pathways. Ports and harbours were constructed and elongated several times to prevent silting problems, generating significant sedimentation in updrift sides and huge erosion in downdrift areas.
To mitigate the aforementioned problems, updrift-deposited sediments and maintenance-dredged materials, which, in the past, accumulated in city dumps (ANFUsO and MARTíNEZ, 2005), could be used to nourish downdrift beaches by means of bypassing systems projected on the basis of accurate studies on coastal sediment circulation pathways (HEALY et $a l ., 2002)$. This study is a first step in that direction. The applied methodology allowed us to learn the amount and manner in which the shoreline has been eroding or accreting and has permitted us to propose adequate solutions that can partially solve the problems caused by the general erosion.

Very wide beaches, associated with coastal structures, are observed at Plaja Grande, Donnalucata, and Pozzallo (Figures 2 and 3 ). In all of them, bars, beach-volley camps, and beach facilities have been emplaced in the newly formed drybeach areas, whereas only a narrow strip, close to the shoreline, is used for bathing purposes. In these areas, human leisure activities could be moved inland, and the beach surface area could be reduced without diminishing the recreational use of the beach.

In fact, Plaja Grande beach could be reduced by $100 \mathrm{~m}$ along the existing breakwater; $14,000 \mathrm{~m}^{2}$ of beach would be lost, but the remaining 100-m-wide beach would be enough for local tourist purposes (Figure 5).

At Donnalucata, the beach could be reduced by $24,000 \mathrm{~m}^{2}$ to match the 1977 shoreline position, i.e., its original position before the enlargement of the structure (Figures 2 and 5). It is also possible that considerable volumes of sediments could be obtained by dredging the nearshore zone, close to Donnalucata harbour. The volumes obtained in Plaja Grande and Donnalucata could be used to nourish the Irminio River mouth area, which is where the sediments originated, and the Modica Stream area.

At Pozzallo, beach surface could be reduced by $65,000 \mathrm{~m}^{2}$, to return to the 1977 shoreline position. The large volume of sediments that could be dredged in the nearshore zone should be injected into the Santa Maria del Focallo beach. In this situation, an engineering solution would probably be necessary to stabilize the nourished sand to reduce the action of westerly longshore transport.

Small volumes of sediments could be also obtained from the beaches (and the fronting nearshore zones) blocked by the Punta Secca harbour and especially by the Marina di Ragusa docks. The dredged sediments could be used to nourish the Caucana and Casuzze beaches.

Dealing with beaches that are directly protected by breakwaters, different solutions could be adopted. At Marina di Ragusa, we do not recommend any kind of action because the formed beach is relatively narrow and is valuable for tourism. The breakwaters at Donnalucata are overdimensioned and impact the view; they should be moved inland or be lowered to permit erosion of part of the formed beaches. Sediments would be reintegrated in the system and transported eastward to replenish Modica Stream area.

\section{CONGLUSIONS}

The results of the present study show that aerial images analyzed by GIS can be used as very useful and appropriate 


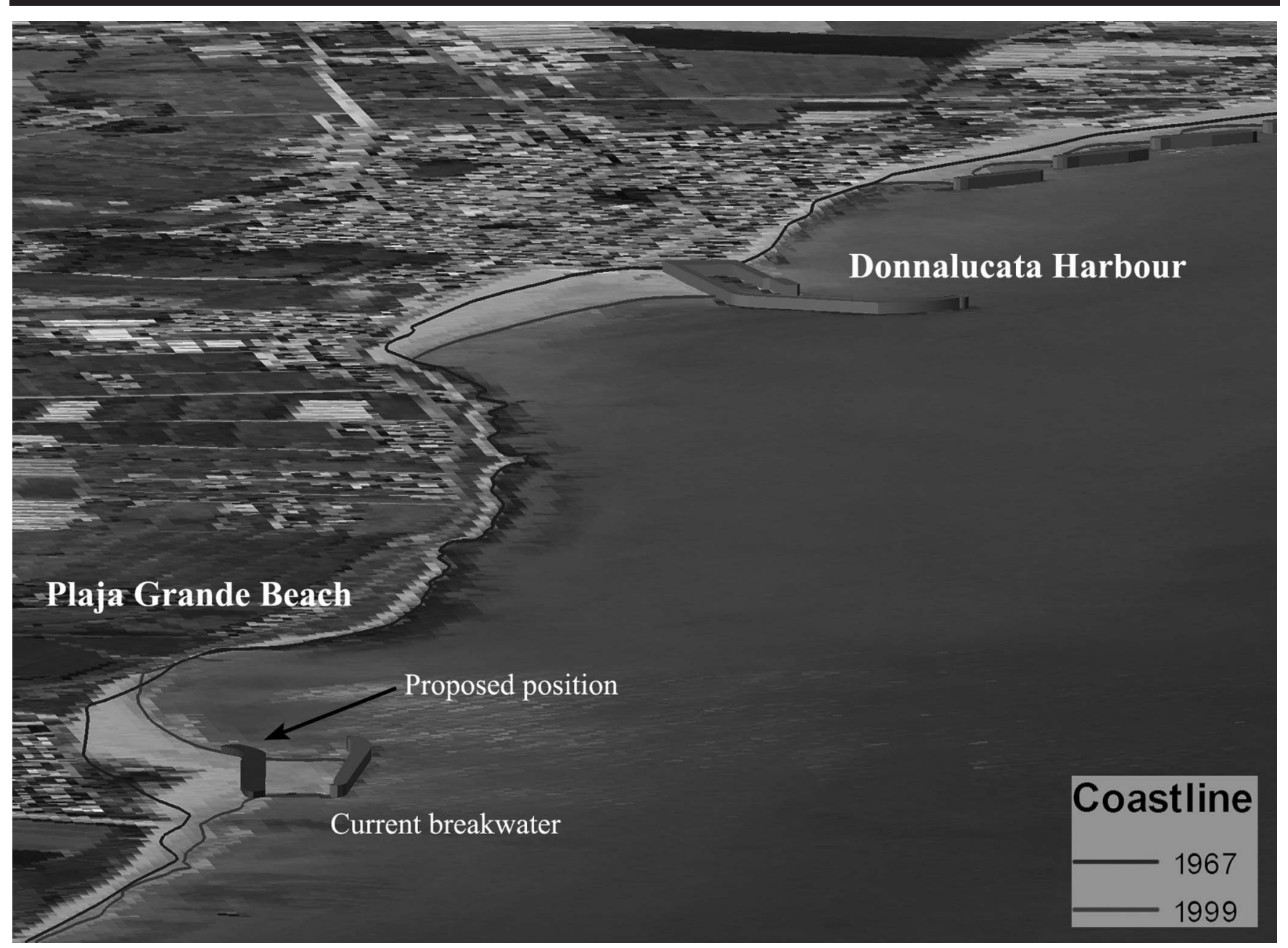

Figure 5. Proposed actuations at Plaja Grande and Donnalucata beaches. For a color version of this figure, see page 133.

tools for the detection of shoreline changes and the impacts of human structures over the studied timescales. In fact, the applied methodology allows the quantification of the main erosion/accretion areas and the characterization of coastal compartmentalization and sedimentary-transport pathways. This information is indispensable to the design of a coastal erosion management plan according to the natural beach behaviour.

By contrast, over recent decades, local government planning has not taken these factors into account when constructing and elongating ports and harbours. The consequence of this neglect has been particularly significant in the northern sector because, in the southern sector, any effects are linked to the area close to the Pozzallo port. Thus, the majority of the important structures has given rise to a notable amount of sedimentation on the updrift sides and huge erosion in downdrift areas, counteracted by the construction of breakwaters. Recently, a beach nourishment project has been carried out at Caucana, and other projects have been designed for different eroding areas, i.e., at Casuzze, Modica Stream mouth, and Santa Maria del Focallo beach.
According to the obtained results, these actions represent very local intervention within a general and extended retreating scenario. A general management plan should be based on the release of sediments that are already accumulated in the updrifts and inside of human structures and which correspond to the existing breakwaters, which could be partially dismantled or moved inland. Further, permanent bypassing systems should be installed in correspondence to the most important harbours and ports to restore the previous, natural coastal dynamics.

\section{ACKNOWLEDGMENTS}

We are indebted to Joanne Doherty for revising the quality of the redaction and to Morris Floridia for field assistance.

\section{LITERATURE GITED}

Amore, C. and Randazzo, G., 1993. Textural features of sediments and temporal evolution of the littoral between Capo Passero and Capo Scalambri (South East Sicily): an attempt at automatic zonation. In: Proceedings of the 8th Symposium on Coastal and 
Ocean Management: Coastal Zone '93. (New Orleans, Louisiana), pp. 3277-3295.

Amore, C. and Randazzo, G., 1997. First data on the coastal dynamics and the sedimentary characteristics of the area influenced by the river Irminio's hydrographic basin (SE Sicily). Catena, 30, $357-368$.

ANDERs, F.J. and ByRnEs, M.R., 1991. Accuracy of shoreline change rates as determined from maps and aerial photographs. Shore and Beach, 59(1), 17-26.

ANFuso, G., 1993. Evoluzione Temporale e Caratteristiche Tessiturali dei Sedimenti della Fascia Costiera Compresa tra Punta d'Aliga e la Foce del Fiume Dirillo-Acate. Catania, Italy: University of Catania, Master's thesis, $78 \mathrm{p}$.

ANFuso, G., 1999. Il litorale ragusano compreso tra Cava d'Aliga e la foce del fiume Dirillo. Bollettino Accademia Gioena Scienze Naturali, 31(355), 287-301.

Anfuso, G. and MARTínez, J.A., 2005. Towards management of coastal erosion problems and human structure impacts using GIS tools: case study in Ragusa Province, Southern Sicily, Italy. Environmental Geology, 48, 646-659.

ANONYMous, 2005. Monitoraggio volumetrico, sedimentológico e morfometrico dellintero litorale ibleo. Final Report. Provincia Regionale di Ragusa. $57 \mathrm{p}$.

Berlanga, C. and Ruiz, A., 2002. Land use mapping and change detection in the coastal zone of northwest Mexico using remote sensing techniques. Journal Coastal Research, 18(3), 514-522.

BIRD, E.C., 1996. Submerging coasts. Hoboken, New Jersey: J. Wiley \& Sons. 184 p.

BRAY, M., 1997. Episodic shingle supply and the modified development of Chesil Beach, England. Journal Coastal Research, 13(4), 1035-1049.

Bray, M.; CARTer, D., and Hooke, J., 1995. Littoral cell definition and budgets for central southern England. Journal Coastal Research, 11(2), 381-400.

Bush, D.; Richmond, B., and NeAL, W., 1996. Coastal hazard maps of Puerto Rico: hurricane Hugo impacted portion of the shoreline, Cibuco (Punta Garaza) to Punta Viento. U.S. Geological Survey Report, 96-506, $12 \mathrm{p}$

CARTER, R.W.G., 1988. Coastal Environments. San Diego, California: Academic Press, $617 \mathrm{p}$.

Chuvieco, E., 2000. Fundamentos de Teledetección Espacial. Madrid, Spain: Ediciones Rialp, 567 p.

Clark, J.R., 1996. Coastal Zone Management Handbook. Boca Raton, Florida: CRC Press, $694 \mathrm{p}$.

Cooper, J. and Mclaughlin, S., 1998. Contemporary multidisciplinary approaches to coastal classification and environmental risk analysis. Journal Coastal Research, 14(2), 512-524.

Crowell, M.; Leatherman, S.P., and BuCKLEy, M., 1991. Historical shoreline change: error analysis and mapping accuracy. Journal Coastal Research, 7(3), 839-852.

Crowell, M.; Leatherman, S.P., and Buckley, M., 1993. Shoreline change rate analysis: long term versus short term data. Shore and Beach, 61(2), 13-20.

Dolan, R.; Fester, M.S., and Holme, S.J., 1991. Temporal analysis of shoreline recession and accretion. Journal Coastal Research, 7(3), 723-744.

Dolan, R.; Hayden, B.; May, P., and Suzette, R., 1980. The reliability of shoreline change measurements from aerial photographs. Shore and Beach, 48, 22-29.

Dolan, R.; Hayden, B.; Rea, C., and Heywood, J., 1979. Shoreline erosion rates along the middle Atlantic coast of the United States. Geology, 7, 602-606.

Domínguez, L.; Anfuso, G., and Gracia, F.J., 2005. Vulnerability assessment of a retreating coast in SW Spain. Environmental Geology, 47, 1037-1044.

Douglas, B.C. and Crowell, M., 2000. Medium-term shoreline position prediction and error propagation. Journal of Coastal Research, 16(1), 145-152.

El-Asmar, H., 2002. Short-term coastal changes along DamiettaPort Said coast northeast of Nile Delta, Egypt. Journal of Coastal Research, 18(3), 433-441.

Fischer, D.W. and Arredondo, M.C., 1999. Municipal coastal haz- ard planning: Los Angeles and Orange country city responses, California. Journal of Coastal Research, 15(4), 974-984.

Fisher, J. and Overton, M., 1994. Interpretation of shoreline position from aerial photographs. In: Proceedings of the 24th International Conference on Coastal Engineering (Kobe, Japan, ASCE), pp. 1998-2003.

Forbes, D.l; Parkes, G.S.; Manson, G.K., AND KeTCH, L.A., 2004. Storms and shoreline retreat in the southern Gulf of St. Lawrence. Marine Geology, 210(1-4), 169-204.

Gorman, L.; Morang, A., and Larson, R., 1998. Monitoring the coastal environment; part IV: mapping, shoreline changes and bathymetric analysis. Journal Coastal Research, 14(1), 61-92.

Healy, T.; Stephens, S.; Black, K.; Gorman, R.; Cole, R., and Beamsley B., 2002. Port redesign and planned beach renourishment in a high wave energy sandy-muddy coastal environment, Port Gisborne, New Zeeland. Geomorphology, 48, 163-177.

JAYAPPA, K.S.; VIJAYA, G.T., and SUBRAHMANYA, K.R., 2003. Influence of coastal structures on the beaches of southern Karnataka India. Journal Coastal Research, 19(2), 389-408.

JimÉnEZ, J. and SÁNCHEZ-ARCILlA, A., 1993. Short-term coastal response at the Ebro Delta, Spain. Marine Geology, 114, 105-118.

Jiménez, J.; SÁnchez-Arcilla, A.; BoU, J., and Ortiz, M., 1997. Analysing short-term shoreline changes along the Ebro Delta (Spain) using aerial photographs. Journal Coastal Research, 13(4), $1256-1266$.

KELLY, J., 2000. Mapping coastal hazards along a rocky coast with eroding bluffs and beaches. In: Proceedings of the 3rd Symposium on the Iberian Atlantic Margin (Faro, Portugal), 373-374.

Komar, P.D., 1998. Beach Processes and Sedimentation. Englewood Cliffs, New Jersey: Prentice-Hall, $544 \mathrm{p}$.

Komar, P.D. and McDougaL, W.G., 1998. Coastal erosion and engineering structures: the Oregon experience. Journal of Coastal Research, Special Issue No. 4, 77-92.

LeAtherman, S., 1983. Shoreline mapping: a comparison of techniques. Shore and Beach, 51, 28-33.

Lillesand, T. and Kiefer, R., 1987. Remote Sensing and Image Interpretation. 2nd edition. New York: Wiley. $65 \mathrm{p}$.

LizArRaga, R.; ApPendini, C., and Fischer, D., 2001. Planning for beach erosion. a case study, playas de Rosario, B.C. Mexico. Journal Coastal Research, 17(3), 636-644.

Mride, R.A.; Hiland, M.W.; Penland, S.; Williams, S.J.; Byrnes, M.R.; WestPhal, K.A.; JAFFE, B.E., and SALlenger, A.H., 1991 Mapping barrier island changes in Louisiana: techniques, accuracy and results. In: Coastal Sediments '91 (Seattle, Washington, ASCE), pp. 1011-1026.

Moore, L., 2000. Shoreline mapping techniques. Journal Coastal Research, 16(1), 111-124.

MoRTon, R.A, 1978. Analysis of sequential shoreline changes. In: Tanner, W.F. (ed.), Standards for Measuring Shoreline Changes. Tallahassee, Florida: Coastal Research and Department of Geology, Florida State University, pp. 43-48.

PaJAK, M.J. and Leatherman, S., 2002. The high water line as shoreline indicator. Journal Coastal Research, 18(2), 329-337.

Pilkey, O. and Dixon, K., 1996. The Corps and the Shore. Covelo, California: Island Press, $272 \mathrm{p}$.

Runyan, K. and GRIGGs, G., 2003. The effects of Armouring seacliffs on the natural sand supply to the beaches of California. Journal of Coastal Research, 19(2), 336-347.

SAnchez-Arcilla, A.; Jimenez, J., and Valdemoro, H., 1998. The Ebro Delta: morphodynamics and vulnerability. Journal Coastal Research, 14(3), 754-772.

SHORT, A.D., 1999. Beach and Shoreface morphodynamics. New York: Wiley, $379 \mathrm{p}$.

SMITH, G. and ZARRILlo, G., 1990. Calculating medium-term shoreline recession rates using aerial photographic and beach profiling techniques. Journal of Coastal Research, 6(1), 111-120.

Stafford, D., 1971. An Aerial Photogrammetric Technique for Beach Erosion Surveys in North Carolina. Fort Belvoir, Virginia: Coastal Engineering Research Centre.

TANEY, N., 1961. Geomorphology of the South Shore of Long Island, New York. Washington, D.C.: Beach Erosion Board, U.S. Army Corps of Engineers, Technical Memoirs 128, 49 p. 
Thieler, E. and DANFORTH, W., 1994. Historical shoreline mapping: Improving techniques and reducing positioning errors. Journal Coastal Research, 10(3), 549-563.
Zviely, D. and Micha, K., 2003. The environmental impact of the Gaza strip coastal constructions. Journal Coastal Research, 19(4), $1122-1127$.

\section{RESUMEN $\square$}

En el presente trabajo, mediante técnicas de análisis espacial aplicadas a vuelos fotogramétricos y mapas integrados dentro de un proyecto SIG, se han estudiado los cambios de un tramo litoral de $60 \mathrm{~km}$ localizado en el sur de Sicilia, Italia. Las playas así estudiadas muestran importantes cambios morfológicos relacionados con la presencia de estructuras rígidas antrópicas que modifican e interrumpen la dinámica litoral. Este trabajo revela como la mayoría de las playas consideradas están afectadas por fenómenos de erosión progresiva debido a una carencia de sedimentos, puesto que éstos son atrapados por los diques y puertos, aguas arriba de los cuales se desarrollan amplias playas, mientras que aguas abajo de los mismos predominan los fenómenos de retroceso de la línea de costa. Las situaciones de erosión a lo largo del litoral estudiado son consecuencia de la falta de planeamiento, por parte de las autoridades administrativas locales, a la hora de construir y ampliar las instalaciones portuarias y los sistemas de diques exentos que se encuentran repartidas por el litoral. Este trabajo propone alternativas y actuaciones de diferente naturaleza a considerar en futuros proyectos de control de la erosión en el litoral estudiado. 